\title{
Article \\ Quantitative and Qualitative Responses of Soil Water-Extractable Organic Matter to Carbon and Nitrogen Management Practices in Loess Soil
}

\author{
Qin Chen ${ }^{1}{ }^{\oplus}$, Zheng-kui Ge ${ }^{2}$, Rong Chai ${ }^{1}$, Yuan Li ${ }^{1}$, Yu-long Li ${ }^{2}$, Yan-jiang Zhang ${ }^{2}$, Zhi Qu ${ }^{3,4, *}$, Ai-qing Zhao ${ }^{5}$, \\ Xiao-hong Tian ${ }^{2, *}$, Min Duan ${ }^{6}$ and Ming Li $^{2}$ (D) \\ 1 Northwest Land and Resources Research Center, Shaanxi Normal University, Xi'an 710119, China; \\ chenqin@snnu.edu.cn (Q.C.); chai.123@snnu.edu.cn (R.C.); liy681@nenu.edu.cn (Y.L.) \\ 2 College of Natural Resources and Environment, Northwest A\&F University, Yangling 712100, China; \\ gzk13838970999@nwafu.edu.cn (Z.-k.G.); liyulongnwsuaf@gmail.com (Y.-1.L.); zhyjgs@nwafu.edu.cn (Y.-j.Z.); \\ lileaf@nwsuaf.edu.cn (M.L.) \\ 3 Shaanxi Key Laboratory of Land Consolidation, Xi'an 710054, China \\ 4 State Key Laboratory of Eco-Hydraulics in Northwest Arid Region, Xi'an University of Technology, \\ Xi'an 710048, China \\ 5 College of Food Engineering and Nutritional Science, Shaanxi Normal University, Xi'an 710119, China; \\ aqzhao@snnu.edu.cn \\ 6 Key Laboratory of Ecology of Rare and Endangered Species and Environmental Protection, Ministry of \\ Education, Guangxi Normal University, Guilin 541006, China; duanmin0618@mailbox.gxnu.edu.cn \\ * Correspondence: zhiqu@xaut.edu.cn (Z.Q.); txhong@nwafu.edu.cn (X.-h.T.); Tel.: +86-29-8708-0051(X.-h.T.)
}

Citation: Chen, Q.; Ge, Z.-k.; Chai, R.; Li, Y.; Li, Y.-1.; Zhang, Y.-j.; Qu, Z.; Zhao, A.-q.; Tian, X.-h.; Duan, M.; et al. Quantitative and Qualitative Responses of Soil Water-Extractable Organic Matter to Carbon and Nitrogen Management Practices in Loess Soil. Agronomy 2021, 11, 2025 https://doi.org/10.3390/agronomy 11102025

Academic Editors: Gaolin Wu, Zhanhuan Shang and Jian Sun

Received: 13 September 2021

Accepted: 6 October 2021

Published: 9 October 2021

Publisher's Note: MDPI stays neutral with regard to jurisdictional claims in published maps and institutional affiliations.

Copyright: () 2021 by the authors Licensee MDPI, Basel, Switzerland. This article is an open access article distributed under the terms and conditions of the Creative Commons Attribution (CC BY) license (https:// creativecommons.org/licenses/by/ $4.0 /)$.

\begin{abstract}
Soil-dissolved organic matter (DOM) drives the carbon $(\mathrm{C})$ and nitrogen $(\mathrm{N})$ cycles in agroecosystems. Despite many studies on DOM dynamics, hardly any attention has been directed toward DOM quality, particularly DOM composition. The aim of this study was to elucidate how $\mathrm{C}$ and $\mathrm{N}$ management practices alter soil water-extractable organic matter (WEOM) in a loess soil agroecosystem. Field experiments were conducted with a winter wheat monoculture. Three $\mathrm{N}$ fertilization rates $\left(0,120\right.$, and $240 \mathrm{~kg} \mathrm{ha}^{-1}$ year $\left.^{-1}\right)$ were applied for 17 years (2002-2019), combined with five $C$ practices (zero, low, and high rates of sheep manure or wheat straw) for three years (2016-2019). The results reveal that soil organic carbon (SOC) and water-extractable organic carbon (WEOC) concentrations in the topsoil (0-20 cm) were increased by organic amendments considerably but were not affected by $\mathrm{N}$ fertilization. The fluorescence excitation-emission matrix spectra (EEM) of WEOM were resolved to two humic-like components (C1 and C2) and two soluble microbial byproduct-like components (C3 and C4). The proportions of $\mathrm{C} 1$ and $\mathrm{C} 2$ were increased, while the proportion of $\mathrm{C} 3$ was decreased by both $\mathrm{C}$ and $\mathrm{N}$ management practices. In conclusion, organic amendments increased both WEOM quality and its proportion of humic-like components, whereas $\mathrm{N}$ fertilization increased the proportion of humic-like components without variations of WEOM quality in the topsoil of loess soil.
\end{abstract}

Keywords: excitation-emission matrix; loess soil; long-term fertilization; parallel factor analysis; water-extractable organic matter

\section{Introduction}

Soil organic matter (SOM) is critical for both agricultural ecosystems and the global carbon (C) cycle. SOM determines the distribution of soil nutrients, moisture, and aggregates [1,2] - all of which contribute to soil buffering capacity and, in turn, improve crop productivity [3]. Soil organic carbon (SOC) constitutes $\sim 50 \%$ of SOM [4] and represents the largest terrestrial C pool, with an estimated $2400 \mathrm{Pg} \mathrm{C}$ up to a soil depth of $2 \mathrm{~m}$ globally. The SOC pool is considered to be $2-4$-fold the atmospheric pool and 4-8-fold the biotic pool $[5,6]$. Even a minor shift in SOC substantially impacts the amount of $\mathrm{CO}_{2}$ released 
into the atmosphere [7]. It is essential to investigate the factors that influence SOM quantity and quality, particularly anthropogenic factors in agricultural ecosystems. However, studying SOM characteristics-especially molecular properties-remains challenging because physical, chemical, and biological processes all convert dead plant or animal materials into organic compounds that interact with soil minerals [5].

Dissolved organic matter (DOM) is the most active fraction of SOM. Despite having a higher turnover rate than microbial biomass $C, D O M$ is in equilibrium with the native soil C [8]. DOM influences environmental soil chemistry and determines fluvial carbon fluxes $[9,10]$. It participates in the formation of stable SOM while influencing the migration and transformation of heavy metals and organic pollutants [11,12]. DOM also influences soil $\mathrm{C}$ and nitrogen $(\mathrm{N})$ cycles in agroecosystems [13]. The fixation rate of $\mathrm{N}$ from mineral into microbial biomass depends on the availability of the C source for microbial activity [14]. Soil DOM characteristics are determined by SOM composition but are also associated with several rapidly shifting soil processes. Soil DOM dynamics is influenced by seasonality [15], stratification [16], existing crops [17], climate, landform, hydrology, soil texture, and management practices $[18,19]$. Such factors are divided mainly into environmental factors and human activities.

It is essential to (i) restrict DOM studies within specific soil types while maintaining environmental factors, including climate, landform, and soil texture, and then (ii) focus on long-term impacts of anthropogenic factors, such as land use or soil management, in order to minimize the short-term environmental impacts of seasonality, hydrology, and temperature. $\mathrm{C}$ and $\mathrm{N}$ management practices are the most common and important anthropogenic factors in agroecosystems, both of which are applied globally and have a profound influence on soil DOM [17,20]. Soil C and N cycles are inseparable processes. A study found that the effect of $\mathrm{N}$ fertilization on soil respiration is determined by labile organic C; it is stimulatory under low levels of labile organic $\mathrm{C}$ and inhibitory at higher levels of labile organic C [21]. The effect of $\mathrm{N}$ fertilization on SOC sequestration depends on two competing processes - the stimulation of organic matter decomposition and the subsequent increase in plant biomass productivity and residue return to the soil [22]. It is essential to understand how $\mathrm{C}$ and $\mathrm{N}$ management practices influence the quantity and quality of soil DOM in agroecosystems.

DOM can be extracted from the soil with or without disturbance to the soil structure, and disturbance-free extraction is preferred in studies exploring soil-DOM-microbe interactions. Water-extractable organic matter (WEOM) is the fraction of DOM extracted by agitating soil samples in water without soil structure disturbance [19]. Based on WEOM analysis, Zhang et al. [23] investigated the influence of land use on DOM quality in soils in arid and semi-arid regions. Although studies on DOM dynamics provide a chance to learn about SOM qualitatively, little attention has been paid to soil DOM composition; this is largely due to the challenges associated with DOM detection.

Soil DOM composition is complex, including plant and animal residues, semi-decomposed organic materials, and stable humic acids [24]. Numerous studies have evaluated soil DOM quantity based on dissolved organic C (DOC) concentrations [25,26]. Few studies have explored the molecular properties of soil DOM because of the limited analytical approaches available [27]. Excitation-emission matrix (EEM) fluorescence spectroscopy is an efficient approach for the rapid analysis of DOM fluorescence characteristics in water bodies, soil samples, and extracellular polymers produced by algae [28-31]. The application of parallel factor (PARAFAC) analysis resolves the complex fluorescence EEM spectra of soil DOM into individual components [32-34]. Based on EEM-PARAFAC analysis, DOM composition can be analyzed and compared among treatments.

In China, nearly $40 \%$ of dry land (including $56 \%$ of traditional winter wheat cultivation areas) is distributed on the Loess Plateau, with severe soil erosion [35]. We hypothesized that $\mathrm{C}$ and $\mathrm{N}$ management practices could alter the DOM in the loess soil agroecosystem. We conducted long-term field experiments to test how $\mathrm{C}$ and $\mathrm{N}$ management practices influence WEOM quantitatively and qualitatively based on EEM-PARAFAC analysis. The 
results of the present study are useful to understand the long-term impacts of $\mathrm{C}$ and $\mathrm{N}$ management practices on soil organic $C$ transformation and sequestration in the Loess Plateau region.

\section{Materials and Methods}

\subsection{Study Site}

The field site was at the Experimental Farm $\left(34^{\circ} 17^{\prime} 44^{\prime \prime} \mathrm{N}, 108^{\circ} 04^{\prime} 10^{\prime \prime}\right.$ E, $524.7113 \mathrm{~m}$ a.s.l) of Northwest A\&F University, Yangling, Shaanxi Province, China. It is in a loess tableland on the southern edge of the Loess Plateau, north of the Weihe River. This region has a continental monsoon climate with annual averages of $13.0^{\circ} \mathrm{C}$ temperature, $632 \mathrm{~mm}$ precipitation, and $990 \mathrm{~mm}$ evaporation. The soil is a loess-origin silt loam Eum-Orthic Anthrosol (Cumulic Haplustalf, USDA taxonomy). The dominant cropping system in this region is mainly the wheat/corn system. The physiochemical characteristics of this soil prior to the current study were previously reported in [36].

\subsection{Experimental Design}

The experiment was a randomized complete block design consisting of three $\mathrm{N}$ fertilization treatments $\left(0,120\right.$, and $240 \mathrm{~kg} \mathrm{~N} \mathrm{ha}^{-1}$ year $\left.^{-1}\right)$ and five organic amendment treatments (zero, low, and high rates of sheep manure or wheat straw; Table 1). The three $\mathrm{N}$ fertilization treatments (denoted N0, N120, and N240) were performed from 2002 to 2019, and the five organic amendment practices (denoted CK, S1, S2, M1, and M2) were applied from 2016 to 2019 under each $\mathrm{N}$ fertilization treatment, yielding a total of 15 treatments. Each treatment had four replicates, with 60 plots $(6 \mathrm{~m} \times 9.9 \mathrm{~m}$ each $)$ at $1 \mathrm{~m}$ intervals.

Table 1. Experimental design of the study in the loess soil agroecosystem over a 17-year period.

\begin{tabular}{|c|c|c|c|c|c|}
\hline Factor & Level & Label & Material & $\begin{array}{c}\text { Treatment } \\
\text { kg ha }^{-1} \text { year }^{-1}\end{array}$ & Duration \\
\hline \multirow{5}{*}{ Organic amendment } & No organic amendment & CK & - & 0 & 2002-2019 \\
\hline & Straw return at low rate & S1 & Air-dried former wheat straw & 7500 & \multirow{4}{*}{ 2016-2019 } \\
\hline & Straw return at high rate & $\mathrm{S} 2$ & Air-dried former wheat straw & 15,000 & \\
\hline & Manure addition at low rate & M1 & Sheep manure & 30,000 & \\
\hline & Manure addition at high rate & M2 & Sheep manure & 45,000 & \\
\hline \multirow{3}{*}{$\mathrm{N}$ fertilization } & No N & No & - & 0 & \multirow{3}{*}{ 2002-2019 } \\
\hline & $\mathrm{N}$ applied at low rate & N120 & urea $(\mathrm{N}: 46.7 \%)$ & 120 & \\
\hline & $\mathrm{N}$ applied at high rate & N240 & urea $(\mathrm{N}: 46.7 \%)$ & 240 & \\
\hline
\end{tabular}

A winter wheat (Triticum aestivum L.) cultivar, "Xiaoyan 22", was planted in monoculture from 2002, with an annual growth cycle from October to the next June. In total, 30 rows were spaced $20 \mathrm{~cm}$ apart in each plot. $P$ fertilizer in the form of calcium phosphate $\left(\mathrm{P}_{2} \mathrm{O}_{5} 16 \%\right)$ was applied at a rate of $100 \mathrm{~kg} \mathrm{ha}^{-1}$ year $^{-1}$. All chemical fertilizers and organic amendments were applied to the soil surface as basal fertilizers at their indicated rates (Table 1 ) and then turned into the soil using a rotary cultivator before sowing every mid-November.

\subsection{Soil Sampling}

Soil sampling was conducted after the wheat harvest, on 13 June 2019. In each plot, topsoil samples $(0-20 \mathrm{~cm})$ were collected from five points in an S-shaped pattern using a $6 \mathrm{~cm}$ diameter auger and mixed fully to form a $2 \mathrm{~kg}$ composite sample. After removing plant residues manually, the soil samples were air-dried, ground, and passed through a $1 \mathrm{~mm}$ sieve. All samples were kept in polyvinylchloride bottles and stored in the dark at room temperature $\left(20^{\circ} \mathrm{C}\right)$ until use. 


\subsection{Soil Analysis}

\subsubsection{SOC Analysis}

The ground soil sample $(0.5000 \mathrm{~g})$, which had been passed through a $0.25 \mathrm{~mm}$ sieve, was weighted for SOC, and SOC was determined using the Walkley-Black potassium dichromate-sulfuric acid oxidation procedure [37].

\subsubsection{WEOC Analysis}

The ground soil sample ( $3.00 \mathrm{~g}$ ), which had been passed through a $0.25 \mathrm{~mm}$ sieve, was added into a $50 \mathrm{~mL}$ centrifuge tube containing $30 \mathrm{~mL}$ of distilled water. The suspension was incubated immediately in a water bath oscillator at $60^{\circ} \mathrm{C}$ and $280 \mathrm{rpm}$ for $30 \mathrm{~min}$ [38]. After centrifugation $(11,000 \times g$ for $6 \mathrm{~min})$, the supernatant was filtered through a $0.45 \mu \mathrm{m}$ membrane. The WEOC concentration in the filtrate was measured using a total organic $\mathrm{C}$ analyzer (TOC-L CPN; Shimadzu, Kyoto, Japan).

\subsubsection{Fluorescence EEM Spectra Analysis}

All the filtrates used in WEOC analysis were diluted to $8 \mathrm{mg} \mathrm{L}^{-1}$ of WEOC to avoid fluorescence quenching caused by high DOC concentrations. Fluorescence EEM spectra were obtained using a spectrofluorometer (F97 Pro; Lengguang Technology Co., Ltd., Shanghai, China) equipped with a $640 \mathrm{~W}$ xenon lamp at room temperature $\left(20^{\circ} \mathrm{C}\right)$. The spectra were recorded in scan mode at a speed of $1200 \mathrm{~nm} \mathrm{~min}^{-1}$, excitation wavelength of

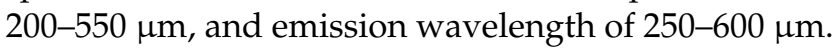

\subsection{Data Analysis}

PARAFAC analysis of the EEM spectra was performed using the DOMFluor toolbox in MATLAB v7.0 (Mathworks, Natick, MA, USA), as described by Stedmon and Bro [26]. The humification index (HIX) was used to evaluate the humification extent of the DOM [39]. This index was calculated with the fluorescence intensity over the $435-480 \mathrm{~nm}$ region divided by the sum of the fluorescence intensity over the 300-345 nm and 435-480 nm regions at the excitation wavelength of $254 \mathrm{~nm}$. The ratio of the fluorescence intensity of peak $\beta$ to peak $\alpha(\beta: \alpha)$ was used to evaluate the relative contribution of recently derived DOM $[40,41]$. At the excitation wavelength of $310 \mathrm{~nm}, \beta$ was the fluorescence intensity at $380 \mathrm{~nm}$, and $\alpha$ was the maximum fluorescence intensity observed between 420 and $435 \mathrm{~nm}$.

Statistical analysis was conducted using IBM SPSS Statistics v23 (IBM Corp., Armonk, NY, USA). A two-way analysis of variance, followed by Fisher's LSD test, was performed to evaluate the differences in SOC concentration, WEOC concentration, WEOM composition, and fluorescence properties among the organic amendment and $\mathrm{N}$ fertilization treatments. Significant differences were reported at $p<0.05$. Redundancy analysis was performed to evaluate the effects of $\mathrm{C}$ and $\mathrm{N}$ management practices on SOC and DOM characteristics using CANOCO v4.5 (Centre for Biometry, Wageningen, The Netherlands).

\section{Results}

\subsection{Soil Organic Carbon Concentrations}

The SOC concentrations in the topsoil were influenced by organic amendment but not by $\mathrm{N}$ fertilization (Table 2). There was no significant interaction effect between the two anthropogenic factors on SOC concentrations. The SOC concentrations were increased by straw return and manure addition in the order of M2 $>$ M1 $>$ S2 $>$ S1 (Figure 1). Manure addition at a high rate (M2) led to the greatest increase in SOC. The SOC concentrations under different $\mathrm{N}$ fertilization rates were increased by $91.5 \%$ (N0), 98.8\% (N120), and $88.9 \%$ (N240), compared with the control treatment with no organic amendment (CK). 
Table 2. The effects of nitrogen (N) fertilization and organic amendment practices on soil organic carbon (SOC) and water-extractable organic matter (WEOM) in the topsoil in winter wheat fields based on two-way analysis of variance.

\begin{tabular}{|c|c|c|c|c|c|c|c|c|c|}
\hline \multirow{2}{*}{ Source of Variation } & \multirow{2}{*}{ df } & \multirow{2}{*}{ SOC } & \multirow{2}{*}{ WEOC } & \multicolumn{4}{|c|}{ WEOM Components } & \multicolumn{2}{|c|}{ Fluorescence Index } \\
\hline & & & & $\mathrm{C} 1$ & $\mathrm{C} 2$ & $\mathrm{C} 3$ & $\mathrm{C} 4$ & HIX & $\beta: \alpha$ \\
\hline $\mathrm{N}$ fertilization & 2 & ns & ns & $<0.001$ & 0.010 & 0.011 & ns & ns & 0.006 \\
\hline Organic amendment & 4 & $<0.001$ & $<0.001$ & 0.001 & 0.003 & $<0.001$ & 0.013 & 0.001 & $<0.001$ \\
\hline $\begin{array}{c}\mathrm{N} \text { fertilization } \times \text { organic } \\
\text { amendment }\end{array}$ & 6 & ns & ns & 0.007 & 0.009 & ns & ns & ns & ns \\
\hline
\end{tabular}

ns, not significant at $p \leq 0.05$.

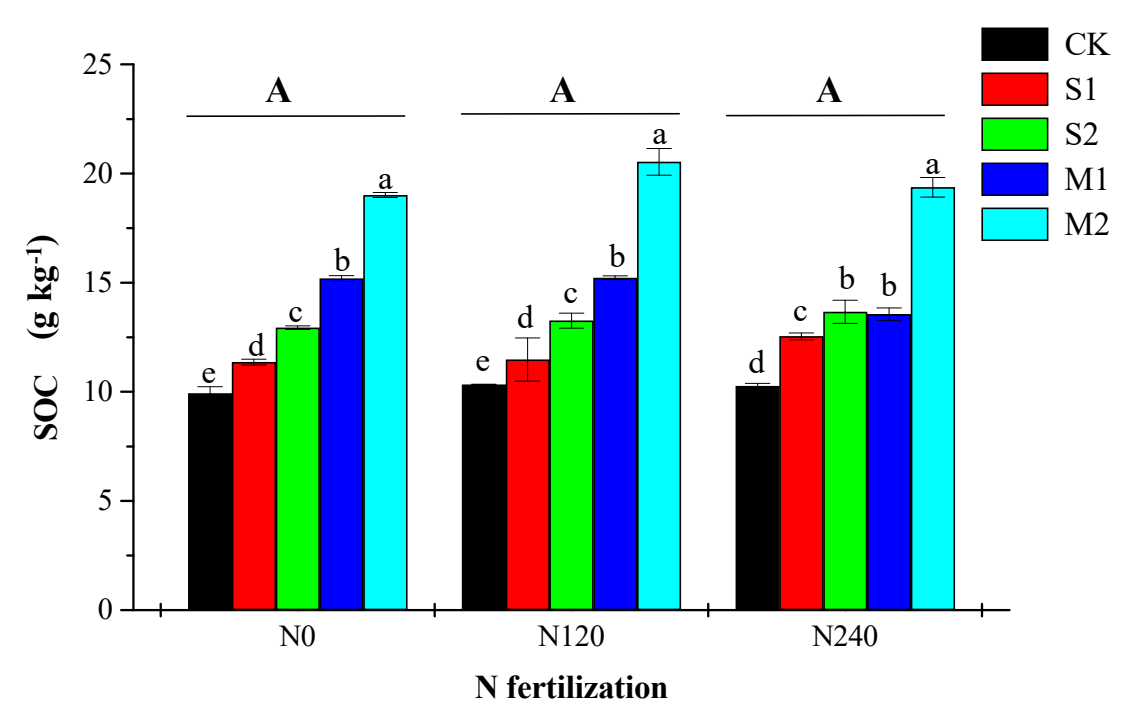

Figure 1. Soil organic carbon (SOC) concentrations under various carbon $(\mathrm{C})$ and nitrogen $(\mathrm{N})$ management treatments. $\mathrm{N}$ fertilizer was applied for 17 years with urea (N0 = control with no $\mathrm{N}$ fertilization; $\mathrm{N} 120=\mathrm{N}$ fertilization at $120 \mathrm{~kg} \mathrm{ha}^{-1}$ year $^{-1} ; \mathrm{N} 240=\mathrm{N}$ fertilization at $240 \mathrm{~kg} \mathrm{ha}^{-1}$ year $^{-1}$ ). Organic amendments were applied for 3 years with wheat straw or sheep manure (CK = control with no organic amendment; S1 = straw return at $7500 \mathrm{~kg} \mathrm{ha}^{-1}$ year $^{-1}$; S2 = straw return at $15,000 \mathrm{~kg} \mathrm{ha}^{-1}$ year $^{-1} ; \mathrm{M} 1=$ manure addition at $30,000 \mathrm{~kg} \mathrm{ha}^{-1}$ year $^{-1} ; \mathrm{M} 2=$ manure addition at $45,000 \mathrm{~kg} \mathrm{ha}^{-1}$ year $\left.^{-1}\right)$. Different lowercase letters indicate significant differences among the five organic amendment treatments $(p<0.05)$. Different uppercase letters indicate significant differences among the three nitrogen fertilization treatments $(p<0.05)$.

\subsection{Water-Extractable Organic Carbon Concentrations}

The WEOC concentrations in the topsoil increased significantly following the application of organic amendment, while $\mathrm{N}$ fertilization did not influence WEOC concentrations (Figure 2; Table 2). There was no significant interaction effect between the two anthropogenic factors on WEOC concentrations. In addition, the WEOC concentrations did not differ significantly among the four treatments with organic amendments, irrespective of the $\mathrm{N}$ fertilization rate. Under the $\mathrm{N}$ fertilization rate of $\mathrm{N} 120$, the WEOC concentrations in organic amendment treatments increased by $29.8 \%$ (S1), 46.1\% (S2), 52.5\% (M1), and 47.8\% (M2), compared with the control treatment (CK).

\subsection{Water-Extractable Organic Matter Composition}

The EEM spectra of soil WEOM were resolved into four components (C1-C4) by the PARAFAC analysis (Figure 3). These components were considered to be two humic-like (C1 and C2) and two protein-like (C3 and C4) components, on the basis of the results of previous studies (Table 3). 


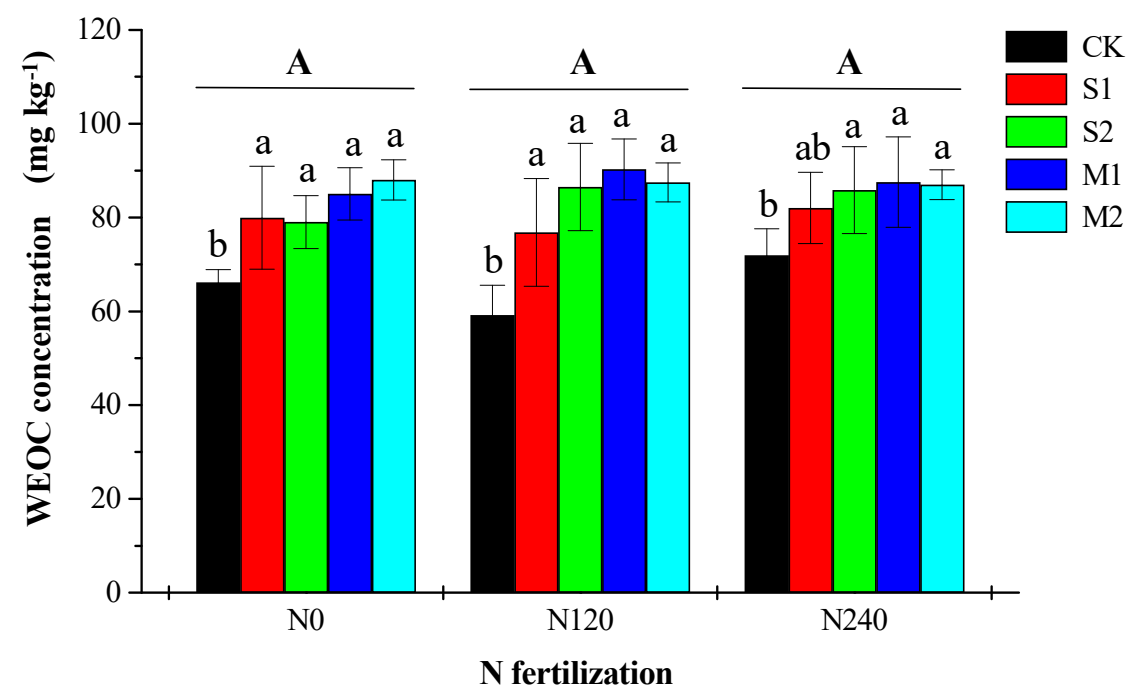

Figure 2. Water-extractable organic carbon (WEOC) concentrations under various carbon (C) and nitrogen $(\mathrm{N})$ management treatments. Treatment abbreviations are defined in Figure 1. Different lowercase letters indicate significant differences among the five organic amendment treatments $(p<0.05)$. Different uppercase letters indicate significant differences among the three nitrogen fertilization treatments $(p<0.05)$.

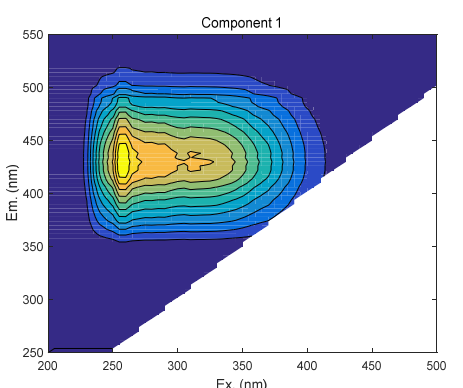

(a)

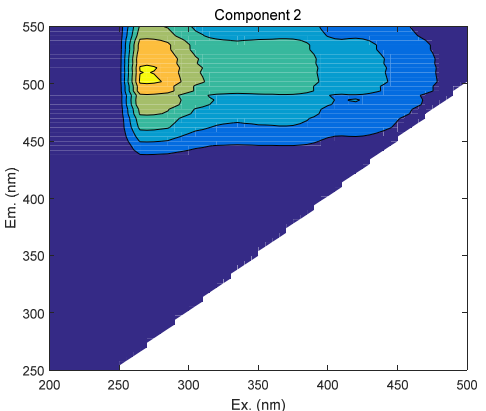

(c)

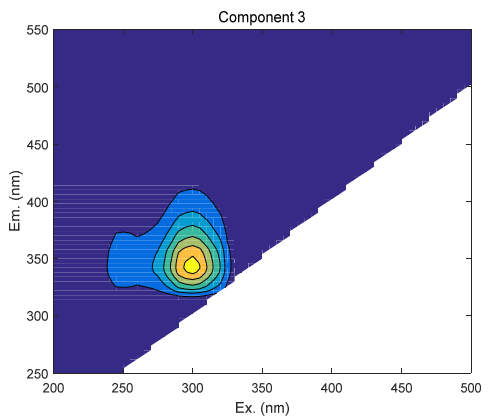

(e)

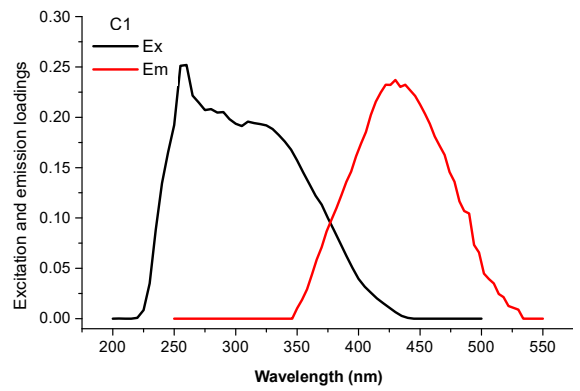

(b)

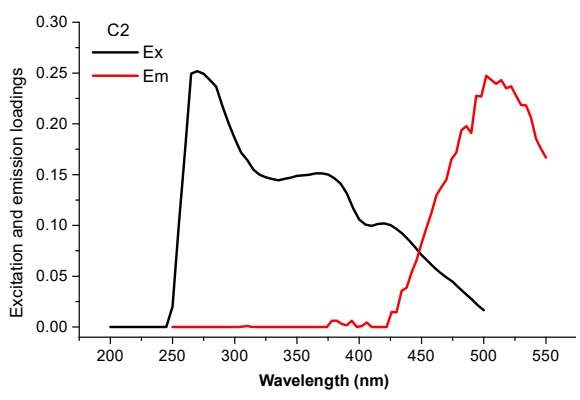

(d)

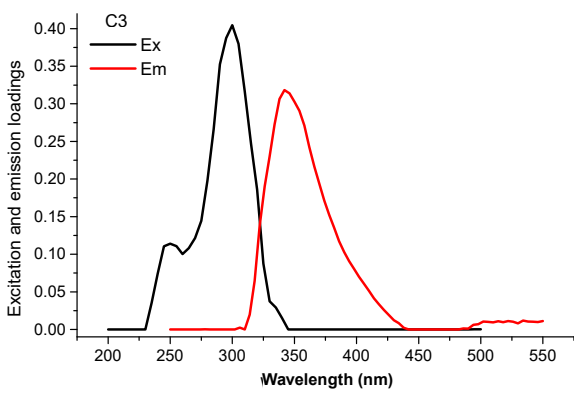

(f)

Figure 3. Cont. 


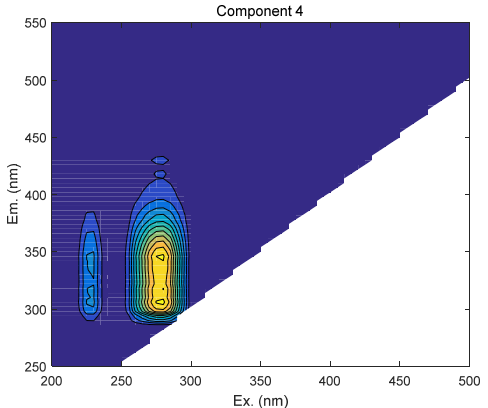

(g)

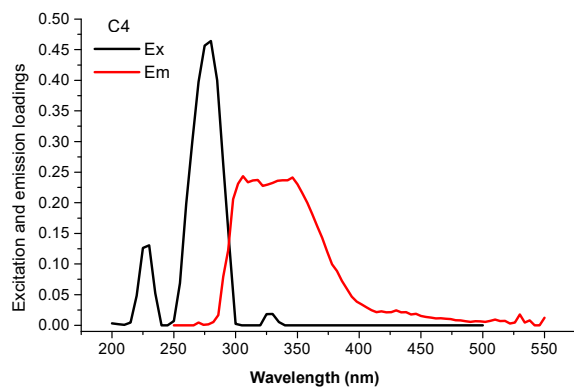

(h)

Figure 3. Excitation-emission matrix spectra and spectral loadings of the four components of water-extractable organic matter identified by parallel factor analysis: (a) excitation-emission matrix spectra of Component 1; (b) spectral loadings of Component 1 ; (c) excitation-emission matrix spectra of Component 2; (d) spectral loadings of Component 2; (e) excitation-emission matrix spectra of Component 3; (f) spectral loadings of Component 3; (g) excitation-emission matrix spectra of Component 4 ; (h) spectral loadings of Component 4.

Table 3. Spectral characteristics of the four components of water-extractable organic matter in the topsoil identified by parallel factor analysis.

\begin{tabular}{|c|c|c|c|c|}
\hline \multicolumn{2}{|c|}{ This Study } & \multicolumn{3}{|c|}{ Previous Studies } \\
\hline Components & $\operatorname{Ex} / \operatorname{Em}(\mathrm{nm})$ & Component & Description and Source Assignment & References \\
\hline $\mathrm{C} 1$ & $260 / 430$ & Humic-like & $\begin{array}{l}\text { Terrestrial humic-like, UV humic-like, strong visible } \\
\text { humic-like, microbially transformed; short excitation } \\
\text { wavelengths; expected to consist of } \\
\text { low-molecular-weight substances }\end{array}$ & [42-45] \\
\hline $\mathrm{C} 2$ & $270 / 502$ & Humic-like & $\begin{array}{l}\text { Long excitation and emission wavelengths; expected to } \\
\text { consist of high-molecular-weight, hydrophobic, and } \\
\text { terrestrial humic-like substances }\end{array}$ & {$[45,46]$} \\
\hline C3 & $250 ; 300 / 342$ & $\begin{array}{l}\text { Soluble microbial } \\
\text { byproduct-like, } \\
\text { tryptophan-like }\end{array}$ & $\begin{array}{l}\text { Tryptophan-like fluorescence; fluorescence peak almost } \\
\text { identical to free tryptophan; derived from } \\
\text { autochthonous processes; related to terrestrial } \\
\text { fluorescent material in forested catchments }\end{array}$ & {$[43,46]$} \\
\hline C4 & $225 ; 280 / 300-350$ & $\begin{array}{l}\text { Soluble microbial } \\
\text { byproduct-like, both } \\
\text { tryptophan-like and } \\
\text { tyrosine-like }\end{array}$ & Agriculturally impacted subtropical wetlands & {$[43,47,48]$} \\
\hline
\end{tabular}

The proportions of $\mathrm{C} 1, \mathrm{C} 2$, and $\mathrm{C} 3$ were influenced by both organic amendments and $\mathrm{N}$ fertilization (Table 2). A significant interaction effect between the two anthropogenic factors was observed for the proportions of $\mathrm{C} 1$ and $\mathrm{C} 2$. Organic amendments increased the proportions of $\mathrm{C} 1$ and $\mathrm{C} 2$ while decreasing the proportion of $\mathrm{C} 3$ significantly under low and medium $\mathrm{N}$ fertilization (N0 and N120; Figure 4). The M2 treatment had the greatest effect on WEOM composition among the different organic amendment practices. When M2 was applied under low $\mathrm{N}$ fertilization (N120), the proportions of $\mathrm{C} 1$ and $\mathrm{C} 2$ increased by $62.2 \%$ and $54.0 \%$, respectively, while the proportion of $\mathrm{C} 3$ decreased by $74.3 \%$ relative to those of the control treatment with no organic amendment (CK). However, the proportions of $\mathrm{C} 1, \mathrm{C} 2$, and $\mathrm{C} 3$ did not differ significantly among the four treatments with organic amendment applied under high N fertilization (N240).

$\mathrm{N}$ fertilization had effects similar to those of organic amendments on soil WEOM composition (Figure 4). The proportions of $\mathrm{C} 1$ and $\mathrm{C} 2$ increased by $8.6 \%$ and $13.5 \%$, respectively, while the proportion of $\mathrm{C} 3$ decreased by $7.7 \%$ under the N120 treatment relative to the N0 treatment with no organic amendment. The corresponding changes in the WEOM composition were much larger under the N240 treatment with no organic 
amendment, as indicated by a $41.4 \%$ increase in C1, a $48.6 \%$ increase in C2, and a $55.4 \%$ decrease in $\mathrm{C} 3$.

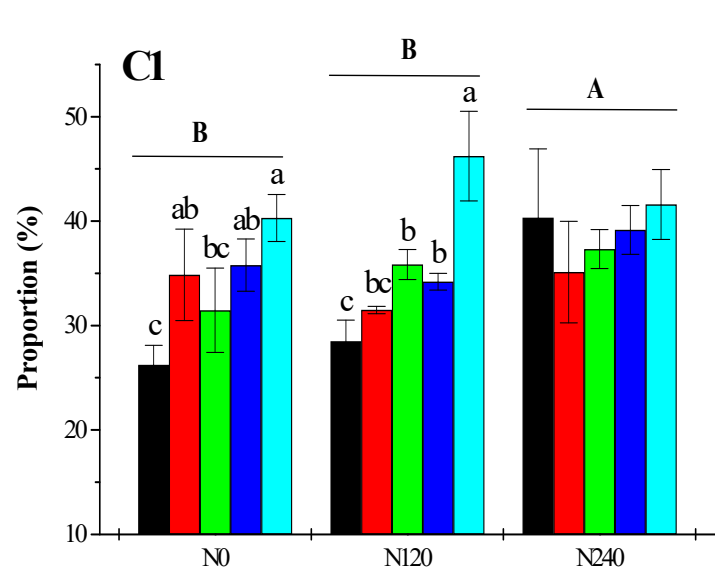

(a)

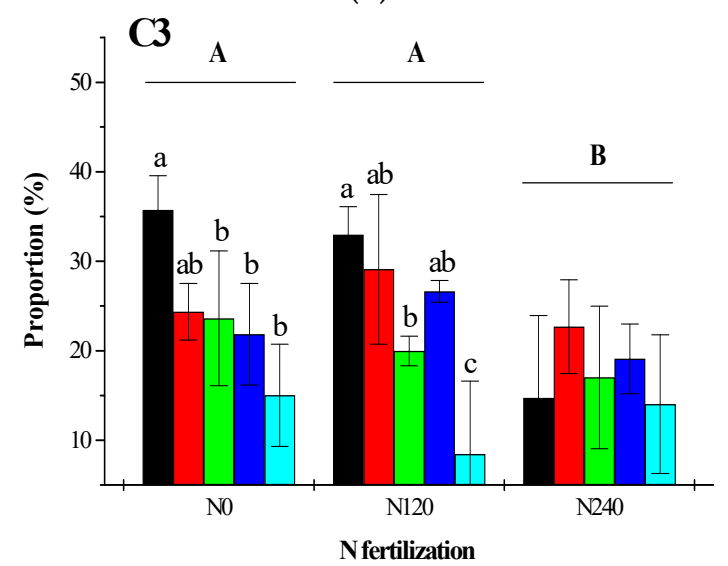

(c)

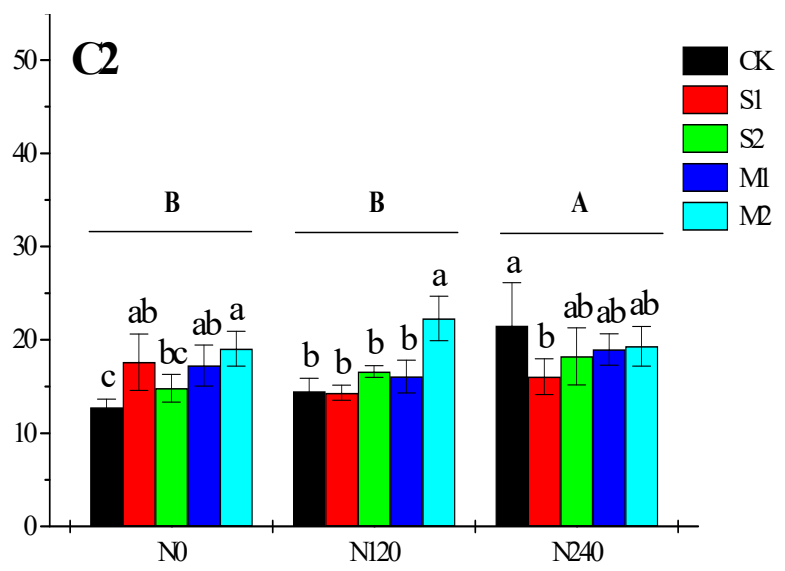

(b)

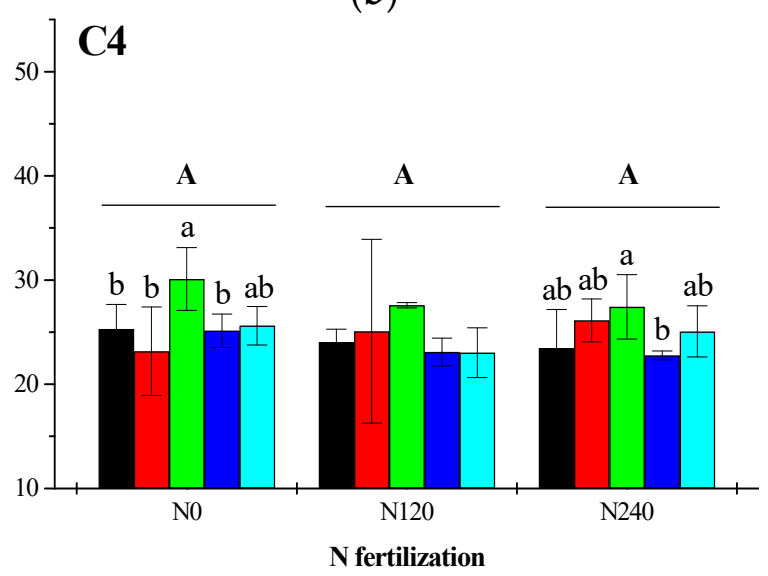

(d)

Figure 4. Proportions of fluorescence intensity for the four components (C1-C4) of water-extractable organic matter: (a) proportions of fluorescence intensity for Component 1; (b) proportions of fluorescence intensity for Component 2; (c) proportions of fluorescence intensity for Component 3; (d) proportions of fluorescence intensity for Component 4. Treatment abbreviations are defined in Figure 1. Different lowercase letters indicate significant differences among the five organic amendment treatments $(p<0.05)$. Different uppercase letters indicate significant differences among the three nitrogen fertilization treatments $(p<0.05)$.

\subsection{Humification Index and the Ratio of $\beta$ to $\alpha$}

Both HIX and $\beta: \alpha$ were influenced by organic amendment, while $\mathrm{N}$ fertilization only influenced $\beta: \alpha$ significantly (Table 2). No significant interaction effects on HIX and $\beta: \alpha$ were detected between the two anthropogenic factors. HIX values increased significantly following the addition of manure (M1 and M2), while they were not altered by straw return (S1 and S2) under the N0 and N120 treatments (Figure 5). HIX did not differ significantly among the five organic amendment practices under the N240 treatment.

The $\beta: \alpha$ ratio was decreased significantly by straw return and manure addition compared with the control treatment with no organic amendment under all three $\mathrm{N}$ fertilization rates (Figure 5). No significant differences in $\beta: \alpha$ were observed among the four treatments with an organic amendment. In addition, the N240 treatment decreased the $\beta: \alpha$ ratio significantly, compared with the N0 and N120 treatments. 


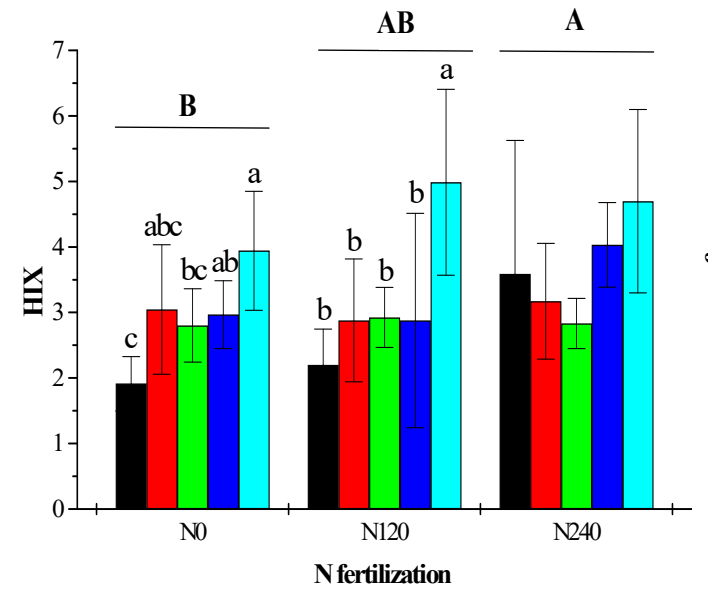

(a)

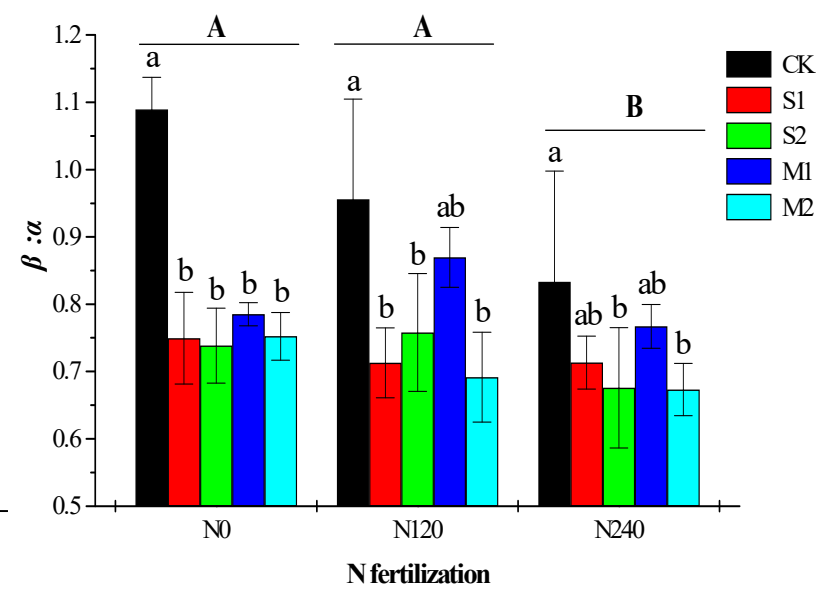

(b)

Figure 5. Fluorescence properties of water-extractable organic matter: (a) humification index (HIX) of water-extractable organic matter; (b) the ratio of fluorescence intensity of peak $\beta$ to peak $\alpha(\beta: \alpha)$ of water-extractable organic matter. Treatment abbreviations are defined in Figure 1. Different lowercase letters indicate significant differences among the five organic amendment treatments $(p<0.05)$. Different uppercase letters indicate significant differences among the three nitrogen fertilization treatments $(p<0.05)$.

\subsection{Relative Importance of C and N Management Practices on SOC and WEOM}

Redundancy analysis revealed that the first two ordination axes represent $65.0 \%$ of the effect of the anthropogenic factors (red dotted arrows) on SOC and DOM characteristics (blue solid arrows; Figure 6). A smaller angle at the intersection indicates a stronger correlation. Compared with the straw return, manure addition was more correlated with $\mathrm{C} 1$ proportion, $\mathrm{HIX}$ value, $\mathrm{C} 2$ proportion, SOC concentration, and WEOC concentration. $\mathrm{N}$ application influenced $\mathrm{C} 1$ and $\mathrm{C} 2$ proportions positively in WEOM, while it had minimal effects on SOC and WEOC concentrations.

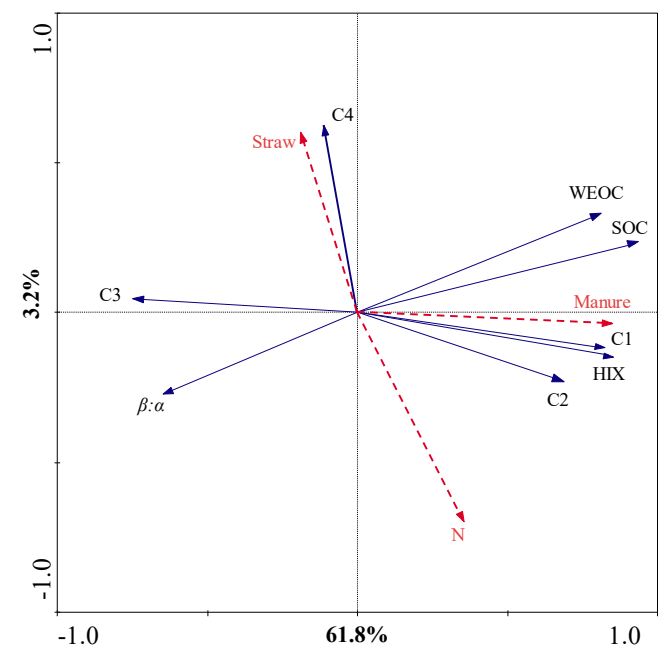

Figure 6. A redundancy analysis bi-plot showing correlations between soil carbon (C) and nitrogen (N) management practices and water-extractable organic matter characteristics. Red dotted arrows represent the $\mathrm{C}$ and $\mathrm{N}$ management practices $(\mathrm{S}=$ straw return, $\mathrm{M}=$ manure addition, $\mathrm{N}=\mathrm{N}$ application); blue arrows represent the four components of dissolved organic matter (C1-C4) and the two fluorescence properties (HIX $=$ humification index, $\beta: \alpha=$ the ratio of peak $\beta$ to peak $\alpha$ ). 


\section{Discussion}

\subsection{Soil Organic Carbon Concentrations Are Increased by Various Organic Amendment Practices}

Straw return and manure addition are direct approaches to applying organic material into the soil. We found that the SOC concentrations in the topsoil of a winter wheat/summer fallow system increased by increasing the application rate of wheat straw and sheep manure (Figure 1). Manure addition was more effective than straw return for application in loess soil, which is consistent with the results of previous studies conducted under winter wheat/soybean rotation [35] and winter wheat/summer maize rotation [49]. The differences between the effects of straw and manure amendments are potentially attributable to the following reasons:

(i) Due to animal digestion and microbial composting processes, the organic compounds in manure are more recalcitrant than those in crop residues. Following field application, composted manure can be stabilized easily through micro-aggregation and organ mineral complexing with silt and clay particles [49]; (ii) fresh crop straw accelerates SOC mineralization, which is referred to as the "positive priming effect" [50,51]. Fontaine et al. [52] found that organic C stored in deep soil layers for over 2000 years could be mineralized rapidly when supplied with fresh carbon, such as cellulose, and Guenet et al. [53] demonstrated that straw has an even greater priming effect on stable SOC than cellulose; (iii) straw has a higher C:N ratio (wheat straw: 60-70:1) than manure (decomposed sheep manure: 16-20:1). According to the "microbial N mining" hypothesis, in $\mathrm{N}$-limited conditions, $\mathrm{N}$-acquiring microbes can decompose $\mathrm{N}$-containing recalcitrant organic matter by using labile $\mathrm{C}$ as an energy source [54]. Therefore, to provide a similar amount of organic $\mathrm{N}$ to a soil ecosystem, less manure would be consumed by $\mathrm{N}$-acquiring microbes when compared with the straw consumed.

The effect of $\mathrm{N}$ fertilization on SOC sequestration is closely associated with soil C management practices. We found that $\mathrm{N}$ fertilization over a 17 -year period did not influence SOC concentrations in the topsoil with or without organic amendment (Figure 1; Table 2). This result indicates that long-term $\mathrm{N}$ fertilization did not disturb the balance between SOC decomposition and organic feedback in the loess soil agroecosystem. Similarly, Dong et al. [18] found that single $\mathrm{N}$ fertilization had minimal effects on SOC concentrations in a wheat-maize cropping system after annual fertilizer applications for 21 years. In addition, long-term $\mathrm{N}$ fertilization over $>23$ years increased soil total $\mathrm{N}$ concentrations in loamy soil; however, there was no increase in SOC concentrations, mainly because $\mathrm{N}$ fertilization stimulated the decomposition of organic $\mathrm{C}$ derived from barley-rice root residues [55]. Stewart et al. [34] reported that SOC concentrations in the topsoil layer $(0-7.5 \mathrm{~cm})$ increased considerably following $\mathrm{N}$ fertilization in a no-tillage system but not in a tillage system.

\subsection{Water-Extractable Organic Carbon Concentrations Are Increased by Various Organic Amendment Practices}

Our results showed that both straw return and manure addition increased WEOC concentrations in the topsoil, irrespective of the $\mathrm{N}$ fertilization rate (Figure 2). This result is consistent with the findings of previous studies on loess soil under a winter wheat/summer maize rotation system [56] and on Haplic Chernozem under winter wheat-spring barley and potato rotation system [57]. We observed no significant differences in soil WEOC concentrations among different organic amendment practices (Figure 2). This phenomenon could be due to the following two reasons:

(i) Soil WEOC concentration is closely related to soil microbial biomass and activity since WEOC provides a readily available substrate for microbial growth [58]. C mineralization enhancement by higher microbial activity would inhibit an increase in soil WEOC concentration. Therefore, WEOC concentration indicates a temporal soil status, which is distinct from steadily accumulated SOC concentration; (ii) WEOC is the most active fraction of SOC and is influenced by both rapidly shifting soil conditions and the intrinsic SOM composition. Such factors could be ranked in the order of decreasing influence: 
land-use type (e.g., forestland, grassland, and cropland), management practice (e.g., tillage, fertilization, and crop species), and environmental conditions (e.g., landscape, climate, soil texture, and soil moisture) [20]. It is still challenging to clearly illustrate the differences among the organic amendment treatments without interference from the above-mentioned environmental factors.

\subsection{Water-Extractable Organic Matter Composition Is Influenced by Both Carbon and Nitrogen Management Practices}

The WEOM extracted from the topsoil was resolved into four components based on the results of our EEM-PARAFAC analysis (Figure 3). Soil WEOM composition was altered with an increase in both organic amendments and $\mathrm{N}$ fertilization rates: (i) the proportions of humic-like substances (C1 and C2) were increased; (ii) the proportion of N-rich tryptophan-like substances (C3) was decreased; (iii) the proportion of C4 was maintained (Table 3 and Figure 4). C1 and C2 are the two most widespread humic-like substances in ecosystems [45]. It was expected that C1 consists of low-molecular-weight substances, while C2 consisted of high-molecular-weight hydrophobic and terrestrial substances (Table 3). The tryptophan-like component, C3, is associated with terrestrial fluorescent material in forested catchments [46]. Our results are consistent with the findings of a ${ }^{13} \mathrm{C}$ study in agricultural soils that concluded humus is a dominant component of WEOM [8]. The increased proportion of humic-like substances was also supported by the increased HIX value and the reduced $\beta: \alpha$ ratio of soil WEOM (Figure 5), which indicate an increase in humification and a reduction in recently derived DOM, respectively.

In the organic amendment treatments, the increased proportions of $\mathrm{C} 1$ and $\mathrm{C} 2$ could be attributed to additional substrates provided for organic $C$ sequestration. This raises the question of how $\mathrm{N}$ fertilization influenced soil WEOM composition. The possible mechanisms can be summarized based on biological and physical factors. Firstly, N-acquiring microbes can exploit labile $\mathrm{C}$ as an energy source and decompose $\mathrm{N}$-containing recalcitrant organic matter in N-limited conditions [46]. It is also a key strategy for plants to acquire high amounts of $\mathrm{N}$ by domesticating microbes that decompose $\mathrm{N}$-containing organic matter via the roots [59]. Therefore, $\mathrm{N}$ fertilization can prevent microbes from decomposing organic matter by supplying sufficient chemical $\mathrm{N}$, which results in organic matter preservation in the soil. Secondly, N-rich organics or proteins/peptides are hydrophilic to C-rich humic substances and can be leached easily by water [60,61]. Conversely, C-rich humic substances are hydrophobic to N-rich organics and tend to be absorbed by soil minerals [62]. Particularly, C2 is reportedly hydrophobic, while it has a strong sorption capacity for gibbsite and goethite [45]. Inamdar et al. [63] found that the DOM fractions in superficial watersheds were composed of humic-like substances, while the DOM fractions from groundwater sources were isolated based on their protein-like fluorescence. Tye and Lapworth [64] revealed that groundwater DOM was generated by the DOM leached from soils in agricultural floodplains. Accordingly, we speculated that the proportions of C-rich organic substances in the soil were increased by $\mathrm{N}$ fertilization, mainly owing to the loss of $\mathrm{N}$-rich organic matter via leaching.

The overall mechanisms by which $\mathrm{C}$ and $\mathrm{N}$ management practices influenced WEOM in the loess soil agroecosystem are illustrated in Figure 7. All four organic amendment practices increased WEOC concentrations but also altered WEOM composition in the topsoil. Manure addition altered WEOM composition to a higher degree than straw return, since more recalcitrant $C$ was retained in the soil, and less $C$ needed to be decomposed. By supplying sufficient chemical $\mathrm{N}$, annual $\mathrm{N}$ fertilization could prevent $\mathrm{N}$-acquiring microbes from decomposing the available organic matter. N-rich organic matter would be reduced by leaching, thereby constitutively and proportionally altering the WEOM composition. SOM comprises a continuum of organic compounds that are decomposed progressively [5]. The results of our study indicate that soil WEOM composition was altered under $\mathrm{C}$ and $\mathrm{N}$ management practices, and this is partly due to changes in the succession of the SOM decomposition process because WEOC is in equilibrium with the native soil C [8]. Organic amendments supplied additional $C$ as a substrate for SOC sequestration processes. 
Long-term $\mathrm{N}$ fertilization altered the $\mathrm{N}$ exploitation strategy of microbial communities by supplying chemical N. Consequently, the succession of the SOM decomposition process was changed.

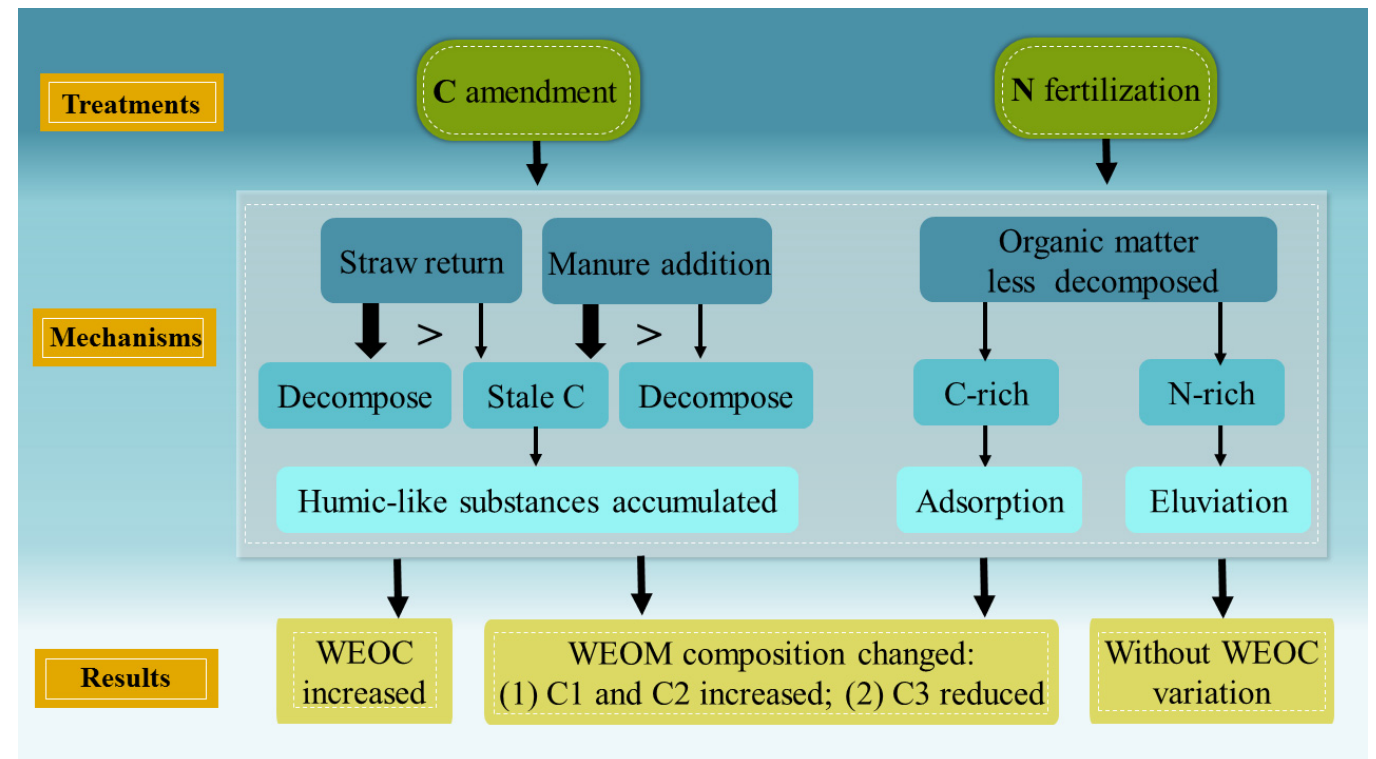

Figure 7. Schematic diagram showing the mechanisms by which carbon (C) amendment and nitrogen (N) fertilization practices quantitatively and qualitatively influence soil organic carbon and dissolved organic matter characteristics.

\section{Conclusions}

In this study, $\mathrm{C}$ and $\mathrm{N}$ management practices were applied in a winter wheat monoculture agroecosystem in loess soil via long-term field experiments. Organic amendments increased both SOC and WEOC concentrations in the topsoil, whereas long-term N fertilization did not significantly affect them. The WEOM composition was altered with similar trends by both organic amendments and $\mathrm{N}$ fertilization treatments. As the organic matter was protected from decomposition by providing sufficient chemical $\mathrm{N}$ to $\mathrm{N}$-acquiring microbes, the N-rich organic matter fractions might be lost via leaching. The results of this study provide new insights into the long-term impacts of $\mathrm{C}$ and $\mathrm{N}$ management practices on DOM in loess soil agroecosystems.

Author Contributions: Investigation, X.-H.T., Q.C., Z.-K.G., Y.-L.L., R.C., M.L. and Y.-J.Z.; data curation, Q.C., Z.-K.G. and M.L.; writing-original draft preparation, Q.C.; writing-review and editing, Z.Q., A.-Q.Z., X.-H.T., M.D. and Y.L.; visualization, Q.C. and Z.-K.G. All authors have read and agreed to the published version of the manuscript.

Funding: This study was supported by the National Natural Science Foundation of China (No. 41907148; No. 42067023; No. 41807041; No. 41831284), the Fund Project of Shaanxi Key Laboratory of Land Consolidation (2019-JC14), the Fundamental Research Funds for the Central Universities, China (No. GK202103128), and a general project of Key Research \& Development Plans in Shaanxi Province (2019NY-119).

Institutional Review Board Statement: Not applicable.

Informed Consent Statement: Not applicable.

Acknowledgments: We thank Wen Li in the College of Natural Resources and Environment, Northwest A\&F University, for help with data analysis.

Conflicts of Interest: The authors declare no conflict of interest. 


\section{References}

1. Reeves, D.W. The role of soil organic matter in maintaining soil quality in continuous cropping systems. Soil Tillage Res. 1997, 43, 131-167. [CrossRef]

2. Balesdent, J.; Chenu, C.; Balabane, M. Relationship of soil organic matter dynamics to physical protection and tillage. Soil Tillage Res. 2000, 53, 215-230. [CrossRef]

3. Zhou, Z.; Gan, Z.; Shangguan, Z.; Zhang, F. Effects of long-term repeated mineral and organic fertilizer applications on soil organic carbon and total nitrogen in a semi-arid cropland. Eur. J. Agron. 2013, 45, 20-26. [CrossRef]

4. Pribyl, D.W. A critical review of the conventional SOC to SOM conversion factor. Geoderma 2010, 156, 75-83. [CrossRef]

5. Lehmann, J.; Kleber, M. The contentious nature of soil organic matter. Nature 2015, 528, 60-68. [CrossRef]

6. Sanderman, J.; Hengl, T.; Fiske, G.J. Soil carbon debt of 12,000 years of human land use. Proc. Natl. Acad. Sci. USA 2017, 114, 9575-9580. [CrossRef] [PubMed]

7. Lal, R. Soil carbon sequestration impacts on global climate change and food security. Science 2004, 304, 1623-1627. [CrossRef]

8. Gregorich, E.G.; Liang, B.C.; Drury, C.F.; Mackenzie, A.F.; Mcgill, W.B. Elucidation of the source and turnover of water soluble and microbial biomass carbon in agricultural soils. Soil Biol. Biochem. 2000, 32, 581-587. [CrossRef]

9. Battin, T.J.; Kaplan, L.A.; Findlay, S.; Hopkinson, C.S.; Marti, E.; Packman, A.I.; Newbold, J.D.; Sabater, F. Biophysical controls on organic carbon fluxes in fluvial networks. Nat. Geosci. 2008, 1, 95-100. [CrossRef]

10. Graeber, D.; Boechat, I.G.; Encina-Montoya, F.; Esse, C.; Gelbrecht, J.; Goyenola, G.; Gücker, B.; Heinz, M.; Kronvang, B.; Meerhoff, M.; et al. Global effects of agriculture on fluvial dissolved organic matter. Sci. Rep. 2015, 5, 16328. [CrossRef]

11. Guggenberger, G.; Kaiser, K. Dissolved organic matter in soil: Challenging the paradigm of sorptive preservation. Geoderma 2003, 113, 293-310. [CrossRef]

12. Kappler, A.; Haderlein, S.B. Natural organic matter as reductant for chlorinated aliphatic pollutants. Environ. Sci. Technol. 2003, 37, 2714-2719. [CrossRef]

13. Hishi, T.; Hirobe, M.; Tateno, R.; Takeda, H. Spatial and temporal patterns of water-extractable organic carbon (WEOC) of surface mineral soil in a cool temperate forest ecosystem. Soil Biol. Biochem. 2004, 36, 1731-1737. [CrossRef]

14. Bjarnason, S. Immobilization and remineralization of ammonium and nitrate after addition of different energy sources to soil. Plant Soil 1987, 97, 381-389. [CrossRef]

15. Embacher, A.; Zsolnay, A.; Gattinger, A.; Munch, J.C. The dynamics of water extractable organic matter (WEOM) in common arable topsoils: I. Quantity, quality and function over a three year period. Geoderma 2007, 139, 11-22. [CrossRef]

16. Franzluebbers, A.J. Soil organic matter stratification ratio as an indicator of soil quality. Soil Tillage Res. 2002, 66, 95-106. [CrossRef]

17. Dong, X.; Sun, H.; Wang, J.; Liu, X.; Singh, B.P. Wheat-derived soil organic carbon accumulates more than its maize counterpart in a wheat-maize cropping system after 21 years. Eur. J. Soil Sci. 2020, 71, 695-705. [CrossRef]

18. Kalbitz, K.; Solinger, S.; Park, J.H.; Michalzik, B.; Matzner, E. Controls on the dynamics of dissolved organic matter in soils: A review. Soil Sci. 2000, 165, 277-304. [CrossRef]

19. Chantigny, M.H. Dissolved and water-extractable organic matter in soils: A review on the influence of land use and management practices. Geoderma 2003, 113, 357-380. [CrossRef]

20. Chantigny, M.H.; Angers, D.A.; Rochette, P. Fate of carbon and nitrogen from animal manure and crop residues in wet and cold soils. Soil Biol. Biochem. 2002, 34, 509-517. [CrossRef]

21. Ni, K.; Ding, W.; Cai, Z.; Wang, Y. Soil carbon dioxide emission from intensively cultivated black soil in Northeast China: Nitrogen fertilization effect. J. Soils Sediments 2012, 12, 1007-1018. [CrossRef]

22. Yang, X.; Li, P.; Zhang, S.; Sun, B.; Chen, X. Long-term-fertilization effects on soil organic carbon, physical properties, and wheat yield of a loess soil. J. Plant Nutr. Soil Sci. 2011, 174, 775-784. [CrossRef]

23. Zhang, Y.; Wang, X.; Wang, X.; Li, M. Effects of land use on characteristics of water-extracted organic matter in soils of arid and semi-arid regions. Environ. Sci. Pollut. Res. 2019, 26, 26052-26059. [CrossRef] [PubMed]

24. Zsolnay, A.; Baigar, E.; Jimenez, M.; Steinweg, B.; Saccomandi, F. Differentiating with fluorescence spectroscopy the sources of dissolved organic matter in soils subjected to drying. Chemosphere 1999, 38, 45-50. [CrossRef]

25. Iqbal, J.; Hu, R.; Feng, M.; Lin, S.; Malghani, S.; Ali, I.M. Microbial biomass, and dissolved organic carbon and nitrogen strongly affect soil respiration in different land uses: A case study at Three Gorges Reservoir Area, South China. Agric. Ecosyst. Environ. 2010, 137, 294-307. [CrossRef]

26. Bertora, C.; Cucu, M.A.; Lerda, C.; Peyron, M.; Bardi, L.; Gorra, R.; Sacco, D.; Celi, L.; Said-Pullicino, D. Dissolved organic carbon cycling, methane emissions and related microbial populations in temperate rice paddies with contrasting straw and water management. Agric. Ecosyst. Environ. 2018, 265, 292-306. [CrossRef]

27. Wang, Y.; Yang, C.; Zou, L.; Cui, H. Optical characteristics and chemical composition of dissolved organic matter (DOM) from riparian soil by using excitation-emission matrix (EEM) fluorescence spectroscopy and mass spectrometry. Appl. Spectrosc. 2015, 69, 623-634. [CrossRef]

28. Stedmon, C.A.; Bro, R. Characterizing dissolved organic matter fluorescence with parallel factor analysis: A tutorial. Limnol. Oceanogr. Meth. 2008, 6, 572-579. [CrossRef]

29. McIntyre, A.M.; Gueguen, C. Binding interactions of algal-derived dissolved organic matter with metal ions. Chemosphere 2013, 90, 620-626. [CrossRef] 
30. Singh, S.; Sudarshan, D.; Inamdar, S. Land application of poultry manure and its influence on spectrofluorometric characteristics of dissolved organic matter. Agric. Ecosyst. Environ. 2014, 193, 25-36. [CrossRef]

31. Zhang, Y.; Liang, X.; Hua, G.; Li, M.; Lin, L. Disinfection byproduct precursors in paddy fields under swine manure application: Reactivity, origins and interception. Agric. Ecosyst. Environ. 2018, 256, 173-183. [CrossRef]

32. Xu, H.; Cai, H.; Yu, G.; Jiang, H. Insights into extracellular polymeric substances of cyanobacterium Microcystis aeruginosa using fractionation procedure and parallel factor analysis. Water Res. 2013, 47, 2005-2014. [CrossRef]

33. Li, M.; Zhang, A.; Wu, H.; Liu, H.; Lv, J. Predicting potential release of dissolved organic matter from biochars derived from agricultural residues using fluorescence and ultraviolet absorbance. J. Hazard. Mater. 2017, 334, 86-92. [CrossRef] [PubMed]

34. Chen, Q.; Jia, R.; Li, L.; Qu, D. Effects of high concentrations of sulfate on dissolved organic matter in paddy soils revealed by excitation-emission matrix analyzing. Chemosphere 2020, 249, 126207. [CrossRef] [PubMed]

35. Stewart, C.E.; Halvorson, A.D.; Delgado, J.A. Long-term N fertilization and conservation tillage practices conserve surface but not profile SOC stocks under semi-arid irrigated corn. Soil Tillage Res. 2017, 171, 9-18. [CrossRef]

36. Wang, S.; Tian, X.; Liu, T.; Lu, X.; You, D.; Li, S. Irrigation, straw, and nitrogen management benefits wheat yield and soil properties in a dryland agro-ecosystem. Agron. J. 2014, 106, 2193-2201. [CrossRef]

37. Walkley, A.; Black, I.A. An examination of the Degtjareff method for determining soil organic matter, and a proposed modification of the chromic acid titration method. Soil Sci. 1934, 37, 29-38. [CrossRef]

38. Nkhili, E.; Guyot, G.; Vassal, N.; Richard, C. Extractability of water-soluble soil organic matter as monitored by spectroscopic and chromatographic analyses. Environ. Sci. Pollut. Res. 2012, 19, 2400-2407. [CrossRef]

39. Fellman, J.B.; Hood, E.; Spencer, R.G.M. Fluorescence spectroscopy opens new windows into dissolved organic matter dynamics in freshwater ecosystems: A review. Limnol. Oceanogr. 2010, 55, 2452-2462. [CrossRef]

40. Parlanti, E.; Wörz, K.; Geoffroy, L.; Lamotte, M. Dissolved organic matter fluorescence spectroscopy as a tool to estimate biological activity in a coastal zone submitted to anthropogenic inputs. Org. Geochem. 2000, 31, 1765-1781. [CrossRef]

41. Wilson, H.F.; Xenopoulos, M.A. Effects of agricultural land use on the composition of fluvial dissolved organic matter. Nat. Geosci. 2008, 2, 37-41. [CrossRef]

42. Yamashita, Y.; Jaffe, R. Assessing the dynamics of dissolved organic matter (DOM) in coastal environments by excitation emission matrix fluorescence and parallel factor analysis (EEM-PARAFAC). Limnol. Oceanogr. 2008, 53, 1900-1908. [CrossRef]

43. Ziegelgruber, K.L.; Zeng, T.; Arnold, W.A.; Chin, Y.P. Sources and composition of sediment pore-water dissolved organic matter in prairie pothole lakes. Limnol. Oceanogr. 2013, 58, 1136-1146. [CrossRef]

44. Williams, C.J.; Yamashita, Y.; Wilson, H.F.; Jaffe, R.; Xenopoulos, M.A. Unraveling the role of land use and microbial activity in shaping dissolved organic matter characteristics in stream ecosystems. Limnol. Oceanogr. 2010, 55, 1159-1171. [CrossRef]

45. Ishii, S.K.L.; Boyer, T.H. Behavior of reoccurring PARAFAC components in fluorescent dissolved organic matter in natural and engineered systems: A critical review. Environ. Sci. Technol. 2012, 46, 2006-2017. [CrossRef] [PubMed]

46. Chen, M.; Jaffé, R. Photo- and bio-reactivity patterns of dissolved organic matter from biomass and soil leachates and surface waters in a subtropical wetland. Water Res. 2014, 61, 181-190. [CrossRef] [PubMed]

47. Lu, F.; Chang, C.H.; Lee, D.J.; He, P.J.; Shao, L.M.; Su, A. Dissolved organic matter with multi-peak fluorophores in landfill leachate. Chemosphere 2009, 74, 575-582. [CrossRef] [PubMed]

48. Santin, C.; Yamashita, Y.; Otero, X.L.; Alvarez, M.A.; Jaffe, R. Characterizing humic substances from estuarine soils and sediments by excitation-emission matrix spectroscopy and parallel factor analysis. Biogeochemistry 2009, 96, 131-147. [CrossRef]

49. Liang, B.; Yang, X.; He, X.; Murphy, D.V.; Zhou, J. Long-term combined application of manure and NPK fertilizers influenced nitrogen retention and stabilization of organic C in Loess soil. Plant Soil 2012, 353, 249-260. [CrossRef]

50. Kuzyakov, Y.; Friedel, J.K.; Stahr, K. Review of mechanisms and quantification of priming effects. Soil Biol. Biochem. 2000, 32, 1485-1498. [CrossRef]

51. Panettieri, M.; Guigue, J.; Prevost-Bouré, N.G.; Thévenot, M.; Lévêque, J.; Guillou, C.L.; Maron, P.; Santoni, A.; Ranjard, L.; Mounier, S.; et al. Grassland-cropland rotation cycles in crop-livestock farming systems regulate priming effect potential in soils through modulation of microbial communities, composition of soil organic matter and abiotic soil properties. Agric. Ecosyst. Environ. 2020, 299, 106973. [CrossRef]

52. Fontaine, S.; Barot, S.; Barre, P.; Bdioui, N.; Mary, B.; Rumpel, C. Stability of organic carbon in deep soil layers controlled by fresh carbon supply. Nature 2007, 450, 277-280. [CrossRef]

53. Guenet, B.; Juarez, S.; Bardoux, G.; Abbadie, L.; Chenu, C. Evidence that stable C is as vulnerable to priming effect as is more labile C in soil. Soil Biol. Biochem. 2012, 52, 43-48. [CrossRef]

54. Chen, R.; Senbayram, M.; Blagodatsky, S.; Myachina, O.; Dittert, K.; Lin, X.; Blagodatskaya, E.; Kuzyakov, Y. Soil C and N availability determine the priming effect: Microbial N mining and stoichiometric decomposition theories. Glob. Chang. Biol. 2014, 20, 2356-2367. [CrossRef] [PubMed]

55. Wang, Y.; Wang, Z.; Zhang, Q.; Hu, N.; Li, Z.; Lou, Y.; Li, Y.; Xue, D.; Chen, Y.; Wu, C.; et al. Long-term effects of nitrogen fertilization on aggregation and localization of carbon, nitrogen and microbial activities in soil. Sci. Total Environ. 2018, 624, 1131-1139. [CrossRef]

56. Liang, B.; Yang, X.; He, X.; Zhou, J. Effects of 17-year fertilization on soil microbial biomass C and $\mathrm{N}$ and soluble organic C and $\mathrm{N}$ in loessial soil during maize growth. Biol. Fertil. Soils 2011, 47, 121-128. [CrossRef] 
57. Embacher, A.; Zsolnay, A.; Gattinger, A.; Munch, J.C. The dynamics of water extractable organic matter (WEOM) in common arable topsoils: II. Influence of mineral and combined mineral and manure fertilization in a Haplic Chernozem. Geoderma 2008, 148, 63-69. [CrossRef]

58. Smolander, A.; Kitunen, V. Soil microbial activities and characteristics of dissolved organic C and N in relation to tree species. Soil Biol. Biochem. 2002, 34, 651-660. [CrossRef]

59. Moreau, D.; Bardgett, R.D.; Finlay, R.D.; Jones, D.L.; Philippot, L.J.; Ecology, F. A plant perspective on nitrogen cycling in the rhizosphere. Funct. Ecol. 2019, 33, 540-552. [CrossRef]

60. Mcknight, D.M.; Bencala, K.E.; Zellweger, G.W.; Aiken, G.R.; Feder, G.L.; Thorn, K.A. Sorption of dissolved organic carbon by hydrous aluminum and iron oxides occurring at the confluence of Deer Creek with the Snake River, Summit County, Colorado. Environ. Sci. Technol. 1992, 26, 1388-1396. [CrossRef]

61. Yu, Z.; Zhang, Q.; Kraus, T.E.C.; Dahlgren, R.A.; Anastasio, C.; Zasoski, R.J. Contribution of amino compounds to dissolved organic nitrogen in forest soils. Biogeochemistry 2002, 61, 173-198. [CrossRef]

62. Ussiri, D.A.N.; Johnson, C.E. Sorption of Organic carbon fractions by spodosol mineral horizons. Soil Sci. Soc. Am. J. 2004, 68, 253-262. [CrossRef]

63. Inamdar, S.; Finger, N.; Singh, S.; Mitchell, M.; Levia, D.; Bais, H.; Scott, D.; Mchale, P. Dissolved organic matter (DOM) concentration and quality in a forested mid-Atlantic watershed, USA. Biogeochemistry 2012, 108, 55-76. [CrossRef]

64. Tye, A.M.; Lapworth, D.J. Characterising changes in fluorescence properties of dissolved organic matter and links to $\mathrm{N}$ cycling in agricultural floodplains. Agric. Ecosyst. Environ. 2016, 221, 245-257. [CrossRef] 